\title{
Conflict-Related Democracy Predictors in Ukraine: Tolerance and Participation Tendencies in Migration-Affected Communities
}

\author{
Svitlana Balinchenko \\ Ph.D., YuriyFedkovych Chernivtsi National University (Chernivtsi, Ukraine) \\ E-mail: sp.balinchenko@gmail.com \\ https://orcid.org/0000-0001-8345-0522
}

Balinchenko, Svitlana (2019) Conflict-Related Democracy Predictors in Ukraine: Tolerance and Participation Tendencies in Migration-Affected Communities. Ukrainian Policymaker, Volume 5, 4-16. https://doi.org/10.29202/up/5/1

In the paper, there have been presented the results of the comparative analysis, based on the empirical data provided in public opinion surveys and civic engagement polls of residents of Ukraine, 2017-2019. The investigation has been aimed at tracing the correlation, on the one hand, between the civic literacy level of population, and proneness of the latter to the impact of conflict-related biases, and populist political agendas, in particular, region-and languagerelated ones, concerning intergroup and intragroup relations between internally displaced persons and host communities. On the other hand, tolerance to otherness, and readiness of citizens to participate in peacebuilding initiatives, are reviewed through the perspectives and risks of further communicative and educational transformations of the conflict-restructured communities in Ukraine; and the conclusion on urgent need in diagnostic and prospective civic literacy and expectations mapping of the entire war-affected population, regardless of the region, outlines the challenge yet to be faced by Ukrainian researchers and policymakers.

Keywords: Ukraine, civic literacy, civic engagement, protracted internal displacement, IDP, tolerance, social cohesion

Received: October 10, 2019; accepted: November 15, 2019

(C) Balinchenko, Svitlana, 2019 


\section{Introduction}

In the Freedom Score 2019 country report on Ukraine, political rights aspect in Ukraine scored 26/40, in particular, political pluralism and participation - 11/16; and the opportunity for the opposition to increase voters' support and gain power through elections having been considered doubtful, according to point B2: "Newer grassroots parties have difficulty competing with more established parties that enjoy the support and financial backing of politically connected business magnates, known as oligarchs" (Aggregate Freedom Score, 2019). The abrupt change of political vector of Ukraine, after 2019 series of elections, has hinged on the background of the intermittent armed combat in eastern Ukraine resulting in over 3,000 civilians having been killed since 2014, and more than 1.4 million citizens having faced protracted internal displacement challenges during the 2014-2019 period. Thus, civic engagement situation in Ukraine, under the contradictory conditions, requires being paid special attention, in order to derive the patterns of citizens' participation and interaction, as well as otherness, community restructuring, competence of civil servants, and impact of the level of the authorities being corrupted on future projecting, as the triggers affecting the longterm political decisions and durable solutions.

In January 2018, in the Public opinion survey to assess the changes in citizens' awareness of civil society and their activities, corruption of the members of Verkhovna Rada (MPs) was considered the biggest obstacle to greater reform process in Ukraine by $46 \%$ of respondents, to compare with $40 \%$ having pointed out war, $37 \%$ - oligarchs, and $33 \%$ - corruption of civil servants, as the factors hindering development of Ukraine (Public opinion survey, 2018: 34); in Freedom Score 2019, corruption of officials was also considered "the main obstacle to effective governance in Ukraine" (Aggregate Freedom Score, 2019).Nevertheless, an "agree/ disagree" question in 2019 Public opinion survey enabled to find out that, noncongruently, $55 \%$ of respondents agreed that "Bribery is an integral part of Ukrainian mentality" (Public opinion survey, 2019: 31); and 51\% totally/rather agreed with the statement that "If you can resolve the issue with the public servants using some reward, most people in Ukraine try to take advantage of this" (Ibidem). At the same time, competence of the MPs passing laws, and that of civil servants implementing laws, was considered important in the reform context, in 2018 , by $17 \%$ and $12 \%$ of respondents, respectively (Public opinion survey, 2018: 34). In 2019, before the parliamentary elections, the respondents pointed out that for the MPs to be seen in the next Verkhovna Rada, there was important honesty and openness about income, $89 \%$; active support of anticorruption reforms, $89 \%$; MPs being experts in public policy areas, 84\% (Public opinion survey, 2019: 36). However, among the claims there were considered significant the features of the MPs-to-be such as "promising more jobs, better salaries and increased pensions", "new faces who have never been in the parliament before", and "those who are often on TV and are well-known to people", by $81 \%, 67 \%$, and $47 \%$, correspondingly (Ibidem), thus making it possible to outline the deficiencies of civic literacy and populism counteraction, the latter to be addressed as the exigencies for the Ukrainian society nowadays.

Ukrainian politics tends to be regarded unpredictable, in 2019 , both by $74 \%$ of citizensrespondents (Public opinion survey, 2019: 37), and in the international survey on freedom (Aggregate Freedom Score, 2019), with consideration of the clean sweep of a victory in elections having been achieved by the Servant of the People (Sluha Narodu) party. The party could not be even traced in the list of the parties getting $2 \%$ or more responses to the question on the parties the respondents would vote for, in January 2018 survey (Public opinion survey, 
2018: 39), and then gained 34\% of support in the survey as of July 2019 (Public opinion survey of residents, 2019: 27). And in the context, populism can be outlined, after Müller (2014), as realization of moralistic imagination in politics, that involves "just like us" identity of the leader, and appeal to the group of citizens situationally having been neglected in the country (Müller, 2014).

Therefore, in the article, there have been studied the dimensions of civic literacy in Ukraine as a complex problem, them involving tolerance and civic engagement aspects, with regard to the current hybrid war context related to the situation of protracted internal displacement, and internally displaced persons (IDPs) representation in the agendas and decision-making processes in Ukraine, as well as with consideration of the populism-driven political shift in Ukraine.

\section{Materials and Methods}

The civic literacy problematics, with the background of war-related restructuring of the communities and, therefore, social cohesion priorities in Ukraine, requires the analysis to be based on the data as follows:

1. Theoretical findings on civic engagement, and the risks related to the society transformation as a result of conflict-imposed migrations and societal challenges.

2. Empirical data based on the public opinion surveys on civic activism (Public opinion survey, 2018; Public opinion survey, 2019; Public opinion survey of residents, 2019), civic engagement polls (Civic Engagement Poll, 2017; National Civic Engagement Poll, 2018) and analytics (Haran et al., 2019), National Monitoring System reports on the situation of internally displaced persons, 20172019 (National Monitoring, 2018; National Monitoring, 2019); as well as the aggregate data provided in the Freedom Score on Ukraine (Aggregate Freedom Score, 2019).

3. Ukrainian legislation on internal displacement, host communities and IDPrelated policies, and durable solutions (On Approval, 2016; On Approval, 2017; Monitoring Report, 2018; 2017-2018, 2018; On Appointing, 2019).

The above-mentioned batches of data have been used to clarify the civic literacy level changes of Ukrainian population, 2017-2019, in particular, in the spheres of otherness evaluation and social cohesion challenges and restoring, under the conditions of the ongoing conflict. The comparative analysis of survey results on IDP-group assessment and self-assessment enables further investigation of the correlation between the issue of a vulnerable "politically neglected group", and the rise of appeal to the populist peacebuilding and reintegration projects, as well as to trace the change of attitude towards the war-related political narratives.

\section{Theoretical background - Migration studies and displacement-driven democracy predictors for Ukraine}

Evaluating the danger of democracy decline, Inglehart (2016) concluded based on the World Values Survey data that "tolerance of minorities is an even stronger predictor than overt support for democracy of how democratic a society actually is" (Inglehart, 2016: 19). An important aspect of civic literacy studies, as suggested by Westheimer and Kahne (2004), is educating 'a good citizen'. For instance, the division of personally-responsible, participatory, 
and justice-oriented patterns of civic education (Westheimer \& Kahne, 2004: 243), can be applied to analysis of individualistic, leadership-related, and exploratory dimensions of civic engagement (Ibidem), as well as, beyond educational framework, in order to assess the intergroup/intragroup relations as just or unjust, and, furthermore, to achieve systemic changes and overcome hindering of social cohesion building process. The frame of assessment refers to the values that have priority in the society, such as tolerance, obedience, and selfexpression, all of them included into the list of important values to be chosen in the World Values Survey (WVS). In 2011, pre-war, survey for Ukraine, obedience values prevailed over self-expression, $40-44 \%$ and $26-40 \%$ of choices, respectively, and tolerance was considered an important value by $51-64 \%$ of respondents, the range being age-related (World Values Survey, 2011: 9, 11, 20). In the context of protracted internal displacement and significant changes in the host communities due to IDPs mass influx in 2014-2016, Crimea having been annexed by the Russian Federation, and the ongoing armed conflict in eastern Ukraine, with open military combats with the Russia-backed forces, and the hybrid war technologies implemented, the right-oriented approach implies not only forming the rules and metarules to regulate the resources in host communities, but to reterritorialize the displaced through adaptation, rather than assimilation and dissolving.

Therefore, in the Ukrainian context, civic literacy study implies otherness distribution tracing, and, taking to account that there are 1,410,615 IDPs in Ukraine as of September 23, 2019 (IOM 2019: 1), approximately 4\% of entire population have been affected by the conflictrelated forced migration, and the issue of tolerance gets a new dimension of estimating the IDP-group not only through the simplified dichotomy of "burden vs. social capital" popular in official sources on the displacement (Thematic report, 2014: 5, 8; Ukraine.Recovery, 2015: 34, 40-44; Sustainable development goals, 2017: 114-115; Migration in Ukraine, 2016: 10; On Approval, 2016; On Approval, 2017), but rather through a multidimensional study of the wider otherness patterns (nationality/gender/employment) in displacement-restructured host communities, the former widely ranging from "minority majority" cases in the settlements of Donetsk and Luhansk oblasts, near the contact line, such as Severodonetsk, Izium, Novogrodivka, Vugledar, to the "negligible" percentage of IDPs, between $0.2 \%$ and $4.69 \%$, in Chernivtsi, Zhytomyr, Vinnytsia, Volyn, Rivne, Zakarpattia oblasts, leading to lack of IDPspecific programmes on the local level, and eventually disappearing of displacement-driven issues from the local authorities agendas (Monitoring Report, 2018: 12, 39).

The theoretical grounds for evaluation of the vulnerable groups' challenges has been suggested in migration studies. For instance, Sabates-Wheeler (2019) considers among displacement disadvantages, over-representation one, when forcibly displaced persons "constitute a disproportionate share of an excluded and marginalized group" (Sabates-Wheeler, 2019); the researcher also distinguishes between displacement-specific and displacementintensified disadvantages of IDPs (Ibidem), them being of importance for Ukraine-related otherness study as well, with consideration of both common problems of IDPs and locals, and the special needs and vulnerabilities arising from forced resettling and ambiguity of outcomes, and being for the country a humanitarian challenge and a development one, at the same time (Kälin \& Entwisle, 2017: 7).Other aspects of migration and adaptation relevant for the study, include mobility, anchoring and gradation of belonging studies (Bauman 2000; Urry 2007; Grzymala-Kazlowska \& Phillimore, 2017; Rajput, 2019); integration rethinking, diversity/superdiversity studies — in the context of migration (Vertovec, 2007; Bradley, 2017; Schinkel, 2019; Favell, 2019; Klarenbeek, 2019; Meissner, 2019; Penninx, 2019); and 
national integration idea transformation described by Anderson (2019), as "methodological de-nationalism" (Anderson, 2019).

The Ukraine-specific challenges of civic engagement, in the current migration context, have been studied through a number of perspectives: conflict-related restructuring of society and vectors of influence (Malyarenko \& Wolff, 2018; Bazaluk, 2017; Dodonov et al., 2017; D'Anieria \& Kuzio, 2019), in particular, the public opinion data analysis on assessment of rule of law in the occupied Crimea (O'Loughlin \& Toal, 2019); otherness-related attitudes to IDPs, for instance, criminalized accentuated image vs. imposed morality, and regionspecific challenges of adaptation to host communities (Smal \& Poznyak, 2016; Bulakh, 2017; Ivashchenko-Stadnik, 2017).

Thus, the paper is aimed at investigation of the following democracy predictors, with regard to the vulnerabilities of the conflict-affected society prone to populism-favourable expectations:

1. Civic literacy level, as a predictor of unbiased response to the situation, and realistic estimation of the authorities functions and limitations; the latter is significant for triggering participation and civic engagement of citizens, without them transferring decision-making and responsibility utterly onto those in power;

2. Tolerance to vulnerable groups, and impact of "Not in My Back Yard" (NIMBY) effect on migration-restructured communities, in particular, regarding attitudes to the "other" groups and readiness to support;

3. The gaps in situational self-assessment of vulnerable groups members (for instance, IDPs), and assessment of the actors by other citizens, as an indicator of both social cohesion, and ability to coordinated actions in implementing durable solutions.

\section{Analysis - Civic literacy level of Ukrainian citizens: 2017-2019 surveys data}

\section{A Ukrainian citizen civic portrait: baseline (2017) and control (2019)}

The civic literacy baseline, with regard to the Russian-instigated occupation and ongoing armed conflict, was investigated in 2017, within the framework of PACT and USAID-supported Civic Engagement Poll, a quantitative survey of Ukrainian population, with a sample size of 2134 residents of Ukraine, the sample design corresponding to the adult population of Ukraine as of 2016, excluding the data collection of Crimea and the non-government controlled areas of Donetsk and Luhansk oblasts of Ukraine. The recent quantitative survey, Public opinion survey to assess the changes in the citizen's awareness of civil society and corresponding activities, was conducted with participation of 2054 Ukrainian adult citizens in June-July 2019; and the data can serve the control for measuring the shifts having taken place in the sections of civic education, main goals of Ukraine apprehension and perception of the vulnerable groups as Other or Alien actors of practical discourses.

In both surveys, the level of civic literacy and civic education results were measured on the basis of 13 questions on the fundamental rights and freedoms of Ukrainian citizens, as well as on government and self-government, local and state levels of budget-forming, and the definition of "Ukrainian nation (2017) / Ukrainian people (2019)". To be considered civically literate, the respondents of the surveys were expected to provide the correct answers to the minimum of 10 questions out of 13 (Civic Engagement Poll, 2017: 69; Public opinion survey, 2019: 49). 
In 2017, there was marked absence of significant difference in civic literacy between gender and age categories, $8-10 \%$ of civically literate citizens among them (Civic Engagement Poll, 2017: 70). In 2019, there was fixed a relevant raise in the proportion, with the total level of civically literate citizens shifting from 8 to $13 \%$, and the distribution in the gender categories splitting from merely equal $9 \%$ for male informants and $8 \%$ for the female ones, to $15 \%$ and $10 \%$ respectively; the age distribution changed dramatically as well, in general, from $8-10 \%$ to $14-15 \%$ for the range of groups including the 18-44 and 55-64-year-old respondents (Civic Engagement Poll, 2017: 71; Public opinion survey, 2019: 51).

The most evident changes in civic literacy level can be traced in the data distributed by regions: the most significant improvements, from 8 to $21 \%$, and from 5 to $10 \%$, have been registered in Kyiv city and the Northern oblasts of Ukraine, correspondingly; a definite raise from 16 to $20 \%$, from 8 to $11 \%$, and from 6 to $8 \%$, occurred in the Southern, Central, and Western regions respectively(Civic Engagement Poll, 2017: 70; Public opinion survey, 2019: 50 ). The only civic literacy level decline situation was registered in the Eastern region of Ukraine, from 8 to $6 \%$ of civically literate citizens (Ibidem), although that can be influenced with the migration processes and instable communities structure in the government-controlled areas (the GCA) of Donetsk and Luhansk oblasts.

The aggregate data show the positive dynamics of the civic education results in most aspects, though it is important to trace the tendencies in the respondents' answers to the basic questions, as they enable to formulate both the educational needs and pitfalls, as well as can serve as a guide to the reintegration obstacles overcoming.

For instance, 49\% of the respondents of 2019 poll (Public opinion survey, 2019, 54) were aware of the people of Ukraine being the bearer of the sovereignty in the country, and, though there is a positive gain from 44\% in 2017 poll (Civic Engagement Poll, 2017: 74), the position of President and the Parliament as the next popular options in the poll results corresponds with the perception of the state as a rule-maker and the bearer of the responsibility for welfare and livelihood, in other sections of the surveys. About $8 \%$ of the respondents steadily consider the President and Verkhovna Rada being potent to appoint even local self-government, based on the data of both surveys (Civic Engagement Poll, 2017: 31; Public opinion survey, 2019: 20).

Therefore, the deviations in civic literacy can be addressed as societal "ozone holes", through which manipulations and information distortions penetrate, in the form of decision-molding mythologemes, and political beliefs, without being critically reviewed by the information recipients; and perception of "we-other" structure in the local communities, as well as wider concepts of "nation" and "the people", add to understanding of the civic engagement outline in Ukraine.

\section{Tolerance and perception of the vulnerable groups in Ukraine: general review}

One of the important questions shaping the attitude towards various groups in the Ukrainian society was formulated in the polls as follows: "Who does the Constitution of Ukraine define as the [Ukrainian nation (2017)] Ukrainian people (2019)?", with the suggested responses including Ukrainians, citizens of Ukraine and foreigners, all people who reside in Ukraine legally, and citizens of Ukraine of all nationalities. In 2017, there prevailed the incorrect answer linking citizenship with nationality, the option "Ukrainians" was chosen by $30 \%$ of the respondents, and the correct answer "citizens of Ukraine of all nationalities" was preferred by $22 \%$. One of the reasons for this could be the formulation of the question that seemed misleading to the respondents due to nation/nationality not being distinguished properly by 
them. The notion "Ukrainian nation" was substituted with "Ukrainian people" in the same set of questions in the civic literacy survey of 2019, and the general distribution changed dramatically: the correct answer "citizens of Ukraine of all nationalities" gaining 32\%, and national identification of the citizen being left behind with $22 \%$ of preferences (Civic Engagement Poll, 2017: 75; Public opinion survey, 2019: 55).Though this particular distribution could have been influenced with the notion change, in the USAID National Civic Engagement Polls as of 2017 and 2018, there was provided another attitude-monitoring question where the respondents were to agree or disagree with the statements, one of which being formulated as follows: "It is ok to think that your nation is better than the rest" (Civic Engagement Poll, 2017: 134; National Civic Engagement Poll, 2018: 44). The general tendency was pervasive in both surveys and permeated in $56-58 \%$ of the positive answers, with higher percentage in the Central and Northern regions of Ukraine, and lower threshold of the positive answers, $42-49 \%$, observed in the Western, Eastern regions, and Kyiv city. The distribution is comparable to another item of this set of statements on agreement/disagreement expression, that is formulated as "It is hard to have a positive attitude towards some ethnicities and nations" (Ibidem). With the disturbing trend of positive answers prevailing, 52\% in 2017 survey in general, the Southern region of Ukraine being the "leader" due to the highest level of hesitation towards the possibility of other ethnic groups' positive perception (Civic Engagement Poll, 2017: 134). In the quantitative survey of 2018, with the sample size of 2073 adult citizens of Ukraine, there was fixed a slight improvement, as the percentage of the agreement expression to the statement lowered to 48\% (National Civic Engagement Poll, 2018: 44). At the same time, the surveys 2017-2018 showed high level of positive attitude towards religious groups, as the statement "Any religious groups have the right to existence" got $66 \%$ of positive answers in 2017, in total, with the highest level of tolerance in the Eastern and Central regions of Ukraine, 70\% and $73 \%$ correspondingly, though the general result dropped to $58 \%$ of agreement responses in 2018 (Civic Engagement Poll, 2017: 134; National Civic Engagement Poll, 2018: 44).

The comparison of the prejudices towards other religious and ethnic groups expression level can also be traced through the otherness perception monitorings included into the polls taken in 2017-2018. There was suggested a list of groups, and the task was to define those the respondent would not like to have as neighbours, and in both surveys, the ethnic group of Roma was the third popular answer, right after drug-addicts and persons who abuse alcohol, and chosen by 51\% of the respondents in 2017 (Civic Engagement Poll, 2017: 132), with the results shifting to 46\% in 2018 (National Civic Engagement Poll, 2018: 42). To compare, 7-8\% of respondents did not tolerate people of other religions, on the community level (Ibidem), thus disclosing that the attitudes based on ethnicity of the communicative actors might be more influential than the officially proclaimed markers of political split, such as language or regionally varying identities. For instance, no more than $3 \%$ of the respondents of the surveys analyzed considered Russian-speaking people as an undesired group for neighbourhood, to compare with $2 \%$ of the respondents choosing this option in regard with Ukrainian-speaking people, the distribution being hardly significant, if compared to $40-47 \%$ of the respondents having negative attitude towards sexual minorities, and $35-45 \%$ of those not willing to share the community space with people with HIV/AIDS (Ibidem). As the latter issues of prejudices are difficult to be applied in the hybrid war manipulations, therefore the Russian propaganda widely exploits the counter-real mythologeme of Russian-speaking population being isolated and discriminated on the community level in Ukraine; especially the mythologeme is productive as Russia-supported impact means in the non-government controlled areas of Ukraine. It has 
become the grounds for the attempts of the Russian World (Russki Mir) project realization and "Russian population defence" agenda of the Russian Federation as a justification of the military intervention and political pressure.

In 2019 survey, the community-related tolerance was measured by means of the question on distinguishing the groups that "most experience violations and limitations of rights and freedoms or a prejudiced attitude on the basis of their social features" (Public opinion survey, 2019,46 ), with the possibility of up to 5 answers choice. The social features being quite a vague category in the context, the respondents still marked the heterogeneous groups of sexual minorities, $25 \%$ responses; IDPs, $19 \%$; and national minorities, $17 \%$, as the most vulnerable ones in the Ukrainian society. Moreover, $42 \%$ of the respondents found this question hard to answer or refused to respond altogether (Ibidem); and $86 \%$ of the sample group stated they do not belong to any discriminated group, to compare with $38 \%$ of the same sample having chosen "yes" in total, ranging from "definitely yes" to "rather yes", to the question "Are you ready to support other groups of people from the list above (groups to which you do not belong) in defending their rights?", while $23 \%$ of the respondents refused or found it hard to answer the question on whether they are ready to support the vulnerable groups in defending the rights (Public opinion survey, 2019: 47).

Thus, in the aspect of readiness to support the vulnerable groups, the issue can be further focused at the particular correlation of otherness between IDPs and members of host communities, especially in view of the gradual drop of military actions support by the population of five oblasts adjacent to the non government-controlled areas (the NGCA), from 1.7 to 1.3 points, 2017-2018 (2017-2018 main changes, 2018), and increase in readiness of respondents from these oblasts to dialogue with the persons from the NGCA, from 5.8 to 6.4 points, 2017-2018 (Ibidem).

\section{IDPs issues in the results of the surveys: assessment and self-assessment}

Nationwide and IDP-related surveys data in Ukraine differ in evaluation of the level of IDP-group of citizens being discriminated. The group is seen as discriminated by one in five respondents of the surveys (Public opinion survey, 2019: 46), although the IDP-specific National Monitoring System Reports (NMS reports) on the situation of internally displaced persons, 2017-2019, show rather low level of discrimination, as self-assessed by IDPs in the context of interactions with the locals and authorities in host communities: approximately $6 \%$ of the key informants still claim discrimination, to compare with 18\%, in 2017; and more than $90 \%$ of IDP-respondents face no discrimination, up to the recent data (National Monitoring, 2018: 45; National Monitoring, 2019: 48).

Comparing the civic engagement data since 2015, as provided in 2017 and 2018 surveys (Civic Engagement Poll, 2017: 18; National Civic Engagement Poll, 2018: 6), there can be traced the tendencies in the answers to the question "What are you personally willing to do to help settling the crisis in the East of Ukraine?" as follows: despite being stable during the period 2015-2017, the data on the respondents willing to support the Ukrainian army and Ukrainian volunteers battalions with funds, food, and equipment dropped significantly in 2018 , from $25-23 \%$ to $21 \%$, and from $23-21 \%$ to $17 \%$ respectively; and the willingness to serve personally in the Ukrainian army and the battalions was expressed by $2-4 \%$ of the respondents in 2015-2017, with the data on the willingness for active participation in the armed combats not included in 2018 survey. At the same time, the answers indicating willingness to contribute funds or volunteer for rebuilding the East after the conflict gained 3-5\% of the 
choices (Ibidem), the former option of support appearing in the polls for the first time in 2017, in the survey on civic engagement.

Although, returning to the discussion on the IDP-related civic engagement, there can be assumed a certain rise in the group of the respondents willing to contribute funds to assist IDPs, from 9 to $15 \%$ during 2015-2018 period; and helping IDPs with shelter, food and probono services varies at about 16\%, as of 2018 survey data (Civic Engagement Poll, 2017: 18; National Civic Engagement Poll, 2018: 6). Thus, in 2018, there was fixed stabilizing of support distribution between military and social support motivations of the Ukrainian citizens: $15-17 \%$ distribution both for supporting IDPs and volunteer battalions, for instance; to be compared with the support distribution of 9\% for the former, and 23\% for the latter, in 2015 (Ibidem).

The mentioned before lack of motivation for rebuilding the East (Donbas) after the conflict can be explained not only with the uncertainty and undefined risks of the ongoing hybrid war with the Russian Federation. In the context of the unpredictable political deviations in Ukraine, but also the priorities distribution demonstrated in the Ukrainian society. The quantitative surveys of the Ukrainian population civic engagement provide the ranking of the most important issues for 2017-2019 period. The respondents were to choose three most important current issues for Ukraine, and in both 2017 and 2018 surveys, economic situation, fighting corruption and the crisis in Donbas were chosen by $46-57 \%$ of the respondents, the economic issues toppling the armed conflict-related problems for more than a half of the respondents (Public opinion survey, 2018: 26).

In 2019 poll on civic engagement, there were suggested two parallel questions, enabling to compare three most important issues chosen by the respondents in relation to Ukraine in general, and fro them personally and their family (Public opinion survey, 2019, 29). In comparison with 2017 and 2018 data, three choices of the most important data for Ukraine in 2019 included fighting corruption, crisis in Donbas and health care, 41-55\%, while economic situation was omitting from the key choices (Public opinion survey, 2018: 26; Public opinion survey, 2019: 29). Although, among the issues important for the respondents personally and their families, the crisis in Donbas was chosen by $27 \%$ only, and, for instance, another wardriven problem, returning of Crimea, was regarded as important by $5 \%$ of the respondents, to compare with $10 \%$ of the same sample group considering it an important current issue for Ukraine in general (Ibidem).

Still, Haran et al. (2019), draw attention to the necessity of life normalization in the GCA of Donetsk and Luhansk oblasts of Ukraine. For instance, in 2017, 23\% of respondents supported the policy of isolation of the occupied territories, and $21.9 \%$ supported the policy of maintaining "the humanitarian ties with the territories to the best extent possible" (Haran et al., 2019: 699); and in 2018, the gap widened significantly, isolation support dropped to $16.8 \%$, and $22.3 \%$ of respondents chose the option of the humanitarian ties development (Ibidem).Therefore, readiness to the dialogue, and vagueness of the compromises acceptable for the current authorities to end the war, as well as "population being tired of the war" factor resulting from the protracted character of the conflict-inflicted challenges, can lead to hasty and strategically insecure reintegration process (On Appointing, 2019), and concessions of Ukraine to other actors, if not guaranteed through a broad "peace deal" (Haran et al., 2019: 702), as well as civic engagement motivation of citizens, based on proper assessment of the conflict- and integration-related political decisions of the authorities. 


\section{Conclusions and recommendations}

The societal-level democracy deviations resulting from the existential insecurity consequences of the armed conflict accompanied with informative manipulations, from the aggressor-state, and "populism-enchanted" population in Ukraine, can be regarded as a conflict-related humanitarian and development challenge. Civic literacy and civic engagement of Ukrainian population are of utter importance in the situation described, as the democracy predictors, such as tolerance, pluralism and participation, form the framework of interactions between Ukrainian citizens, under the conditions of military aggression counteraction, biases and populism insights, as well as reaching, by means of coordinated actions, social cohesion balance in conflict-restructured groups, without either assimilation, or isolation of IDPs in host communities.

Therefore, in terms of the outline for further investigations on the civic literacy and civic engagement challenges in Ukraine, the problematic areas can be referred to as follows:

1. The communicative dimension: the role of groups' assessment and self-assessment overlapping, in estimation of the "other"/opponents' readiness for peacebuilding and reintegration, with particular attention to the GCA / the NGCA residents, members of host communities / IDPs / returnees, and other conflict-driven migration actors in Ukraine;

2. The educational dimension: the empirical data provided in the analyzed public opinion surveys and monitoring reports, due to the objective reasons, lack the information on civic literacy level and civic engagement intentions of the population residing in the temporarily occupied regions; and without the reliable information of the kind, the one-way oriented durable solutions and peacebuilding efforts are still in need of the detailed mapping on the civic literacy deficiencies and expectations of the affected citizens; and thus, the authorities-implemented political navigation towards reintegration and sustainable goals, such as peacebuilding and social cohesion in Ukraine, is rather hopeful and intuitive than rationally backed.

\section{[ㅁ] References}

2017-2018 main changes. (2018). UN SCORE for Eastern Ukraine. https://use.scoreforpeace. org/files/publication/pub_file//Trends2018_UA.pdf

Aggregate Freedom Score Report. Ukraine. (2019). Freedom in the World, 2019. https:// freedomhouse.org/report/freedom-world/2019/ukraine

Anderson, Bridget. (2019). New directions in migration studies: towards methodological denationalism. Comparative Migration Studies 7. https://doi.org/10.1186/s40878-019$0140-8$

Bauman, Z. (2000). Liquid modernity. Cambridge, UK : Polity Press ; Malden, MA: Blackwell. Bazaluk, Oleg. (2017). The Theory of War and Peace: The Geophilosophy of Europe. Cambridge Scholars Publishing.

Bradley, M. (2017). The Impact of Armed Conflict on Displacement. Technical report. Institut Barcelona d'EstudisInternacionals

Bulakh, T. (2017). 'Strangers among ours': state and civil responses to the phenomenon of internal displacement in Ukraine. In Migration and the Ukraine Crisis. A Two-Country Perspective : 49-61. E-International Relations Publishing. Bristol, England. 
Civic engagement poll. (2017). USAID, PACT. https://dif.org.ua/uploads/ pdf/17388921135a2ea86ba91ea7.14461295.pdf

D'Anieria, Paul, and TarasKuzio. (2019). Ukraine after five years of conflict. Eurasian Geography and Economics 60: 1-5.https://doi.org/10.1080/15387216.2019.1635512

Dodonov, R., H. Kovalskyi, V. Dodonova, M. Kolinko. (2017). Polemological Paradigm of Hybrid War Research. Philosophy and Cosmology 19: 97-109.

Ivashchenko-Stadnik, K. 2017. The social challenge of internal displacement in Ukraine: the host community's perspective. In Migration and the Ukraine Crisis. A Two-Country Perspective: 25-48. E-International Relations Publishing. Bristol, England.

Favell, A. (2019). Integration: Twelve Propositions after Schinkel. Comparative Migration Studies, 7. https://doi.org/10.1186/s40878-019-0125-7.

Grzymala-Kazlowska A., and J. Phillimore. (2017). Introduction: rethinking integration. New perspectives on adaptation and settlement in the era of super-diversity. Journal of Ethnic and Migration Studies 44: 179-196. https://doi.org/10.1080/1369183X.2017.1341706

Haran, O., M. Yakovlyev, and M. Zolkina. (2019). Identity, war, andpeace: public attitudes in the Ukraine-controlled Donbas. Eurasian Geography and Economics 60: 684-708. https://doi.org/10.1080/15387216.2019.1667845

Inglehart, R. (2016). How much should we worry? Journal of Democracy 27:18-23.

IOM's Assistance to Conflict-affected People in Ukraine. (2019). Bi-monthly Report. IOM Ukraine, September (2019). http://iom.org.ua/sites/default/files/iom_ukraine_ assistance_report_september_2019_eng.pdf

Kälin, W., and $\bar{H}$. Entwisle. (2017). Breaking the impasse:Reducing protracted internal displacement as a collective outcome - Case Study: Ukraine. United Nations Office for Coordination of Humanitarian Affairs (OCHA). https://reliefweb.int/report/ukraine/ breaking-impasse-reducing-protracted-internal-displacement-collective-outcomecase/.

Klarenbeek, L.M. (2019). Relational Integration: a Response to Willem Schinkel. Comparative Migration Studies, 7. https://doi.org/10.1186/s40878-019-0126-6

Malyarenko, T., and S. Wolff. 2018. The logic of competitive influence-seeking: Russia, Ukraine, and the conflict in Donbas. Post-Soviet Affairs 34: 191-212.

Meissner, F. (2019). Of straw figures and multi-stakeholder monitoring — A response to Willem Schinkel. Comparative Migration Studies, 7. https://doi.org/10.1186/s40878019-0121-y

Migration in Ukraine: Facts and Figures. (2016). IOM Ukraine, http://iom.org.ua/sites/ default/files/ff_eng_10_10_press.pdf

MonitoringReportonRegionalIDPIntegrationProgrammesinUkrainein２018-2019. (2018). Liaison Officer (Radnyk) on IDPs. https://www.humanitarianresponse.info/sites/www. humanitarianresponse.info/files/2019/05/Regional-IDP-integration-programmes-inUkraine-in-2018-2019_eng.pdf

Müller, J.-W. (2014). "The people must be extracted from within the people": Reflections on Populism. Constellations, 21.

National Civic Engagement Poll.(2018). USAID/ENGAGE https://dif.org.ua/uploads/pdf/429 3005015cdac1ba6d0bc6.22197504.pdf

National Monitoring System Report on the Situation of Internally Displaced Persons. (2018). Round 12, December 2018. http://iom.org.ua/sites/default/files/nms_round_12_eng screen.pdf 
National Monitoring System Report on the Situation of Internally Displaced Persons. (2019). Round 14, June (2019). http://iom.org.ua/sites/default/files/nms_round_14_eng_web. pdf

O'Loughlin, John, \& Gerard Toal. (2019). The Crimea conundrum: legitimacy and public opinion after annexation, Eurasian Geography and Economics 60: 6-27.https://doi.org $/ 10.1080 / 15387216.2019 .1593873$

On Appointing the transitional committee of the Verkhovna Rada of Ukraine on issues related to forming and implementation of the government policy on restoration of the territorial integrity and assuring sovereignty of Ukraine. (2019). Regulation of the Cabinet of Ministers of Ukraine, No. 211-IX, as of 17 October 2019, Kyiv. https://zakon.rada.gov. ua/laws/main/211-IX (Ukrainian)

On Approval of the Concept of the Targeted State Program for Recovery and Peacebuilding in the Eastern Regions of Ukraine. (2016). Resolution of the Cabinet of Ministers of Ukraine, No. 892-r, as of 31 August 2016, Kyiv. https://zakon.rada.gov.ua/laws/ show/892-2016-\%D1\%80No. n9(Ukrainian)

On Approval of the Strategy of Integration of Internally Displaced Persons and Implementation of Long-Term Solutions to Internal Displacement until 2020. (2017). Regulation of the Cabinet of Ministers of Ukraine, No. 909-r, as of 15 November 2017, Kyiv. https:// zakon.rada.gov.ua/laws/show/909-2017-\%D1\%80(Ukrainian)

Penninx, R. (2019). Problems of and solutions for the study of Immigrant Integration. Comparative Migration Studies, 7. https://doi.org/10.1186/s40878-019-0122-x.

Public opinion survey of residents of Ukraine. (2019). Rating Group Ukraine, the International Republican Institute's Center for Insightsin Survey Research. June 13-23, (2019). https://mail.google.com/mail/u/0/\#inbox/ KtbxLrjdrrrWHcmVRFKdSLNqkQQjsHFLcg?projector=1\&messagePartId $=0.1$

Public opinion survey to assess the changes in citizens' awareness of civil society and their activities. (2018). USAID, PACT. https://dif.org.ua/uploads/ pdf/3235987555af01ce0267550.88880763.pdf

Public opinion survey to assess the changes in citizens' awareness of civil society and their activities. (2019). USAID, PACT. https://dif.org.ua/uploads/ pdf/1820094705d9ccb76b43dc5.92039369.pdf

Rajput, S. G. (2019). Internal Displacement and Conflict: The Kashmiri Pandits in Comparative Perspective. Routledge

Sabates-Wheeler, R. (2019). Mapping differential vulnerabilities and rights: 'opening' access to social protection for forcibly displaced populations. Comparative Migration Studies, 7. https://doi.org/10.1186/s40878-019-0142-6

Schinkel, W. (2019). Migration Studies: an Imposition (Rejoinder). Comparative Migration Studies 7. https://doi.org/10.1186/s40878-019-0136-4

Smal, V., and O. Poznyak. (2016). Internally displaced persons: social and economic integration in hosting communities (based on materials provided by Vinnytsia Oblast, Zaporizhia Oblast, Ivano-Frankivsk Oblast, and Poltava Oblast). PLEDDG Project. Kyiv-2016. http://pleddg.org.ua/wp-content/uploads/2016/10/IDP-REPORT_V.Smal_ ENG.pdf

Sustainable Development Goals: Ukraine. (2017). National Baseline Report. The Ministry of Economic Development and Trade of Ukraine. http://www.un.org.ua/images/SDGs NationalReportEN_Web.pdf 
Thematicreport.InternalDisplacementin Ukraine.(2014). OSCE, SpecialMonitoring Missionto

Ukraine, 12 August 2014. https://www.osce.org/ukraine-smm/122620?download=true

Ukraine. Recovery and Peacebuilding Assessment. Analysis of Crisis Impacts and Needs in

Eastern Ukraine. (2015). Volume 1: Synthesis Report. EU, UN, WBG, March 2015. https://reliefweb.int/sites/reliefweb.int/files/resources/V1-RPA_Eng_rev2.pdf

Urry, John. (2007). Mobilities. Cambridge-Malden: Polity Press.

Vertovec, Steven. (2007). Super-diversity and its implications. Ethnic and Racial Studies 30: 1024-1054 https://doi.org/10.1080/01419870701599465

Westheimer, J., and J. E. Kahne. (2004). Educating the 'Good Citizen': Political Choices and Pedagogical Goals. Political Science and Politics 37: 241-247. https://doi.org/10.1017/ S1049096504004160

World Values Survey. Ukraine. (2011). Country-Pooled Datafile. Madrid: JD Systems Institute. Www.worldvaluessurvey.org/wvsdc/DC00001/F00007754-WV6_Results Ukraine_2011_v20180912.pdf 